\title{
THE PROGNOSIS IN IDIOPATHIC HYPERCALCAEMIA OF INFANTS
}

\author{
BY \\ R. G. MITCHELL \\ From the Department of Child Health, University of St Andrews, Queen's College, Dundee
}

(RECEIVED FOR PUBLICATION SEPTEMBER 24, 1959)

Two distinct types of idiopathic hypercalcaemia of infants have been recognized; a mild or simple type, in which recovery is said to be complete, and a severe type, which results in death or physical and mental retardation (Lightwood and Stapleton, 1953; Lowe, Henderson, Park and McGreal, 1954). Although most cases conform to one or other type, it has recently become apparent that the distinction is not a clear one, and that cases with features of both types may occur (Russell and Young, 1954; Rhaney and Mitchell, 1956; Joseph and Parrott, 1958). Moreover, a few of the supposedly mild cases have died and autopsy has disclosed nephrocalcinosis, affecting mainly the medulla of the kidney (Rhaney and Mitchell, 1956). Hence it is of some importance to determine whether infants with the simple type who recover clinically sustain any permanent renal damage.

The severe form of idiopathic hypercalcaemia is accompanied by considerable dwarfing (Schlesinger, Butler and Black, 1956; Fellers and Schwartz, 1958), while infants with the simple type show retardation of growth during the acute phase of the illness and often for some time thereafter (Creery and Neill, 1954). It is therefore of interest to know how long this retardation persists after the biochemical disturbance has been corrected.

No full follow-up study has yet been reported although Forfar, Balf, Maxwell and Tompsett (1956) gave some details of four cases followed for one to three years; Creery and Neill (1954) briefly described the progress of their patients up to 18 months after the illness, and there have been reports on single cases (Bonham Carter, Dent, Fowler and Harper, 1955; Smith, Blizzard and Harrison, 1959). With a view to obtaining more detailed information about the prognosis, the progress of all children with the simple type of idiopathic hypercalcaemia seen in Dundee during a period of four years has been followed.

\section{Details of the follow-up study}

From 1953 to 1956 inclusive, 18 infants were diagnosed as having the simple type of idiopathic hypercalcaemia. The principal clinical features of the group have been briefly reviewed elsewhere (Mitchell, 1958) and detailed case histories have been recorded for eight of the infants; Cases 2, 3, 4 and 6 by Lowe et al. (1954); Cases 1 and 2 by Morgan, Mitchell, Stowers and Thomson (1956); and Cases 1 and 3 by Rhaney and Mitchell (1956). In Dundee the criterion now accepted for the diagnosis of hypercalcaemia in infants is a level of plasma calcium above $12.0 \mathrm{mg}$. per $100 \mathrm{ml}$. measured on two separate occasions, using an oxalate-permanganate method for the determination of calcium. During the four-year period, at least five other infants were believed to have idiopathic hypercalcaemia of the simple type (two were included in the report by Lowe and his colleagues in 1954 as Cases 5 and 7), but the above criterion was not fulfilled and they are not included in the group. Of the 18 infants in whom the diagnosis was regarded as established, four died and three of these were studied at necropsy (Rhaney and Mitchell, 1956). The 14 survivors are the subject of this report.

Tests of renal function were carried out on all children who had shown any evidence of possible renal involvement during the original illness, i.e. all those whose urine contained leucocytes at any time during the illness or who had had a level of blood urea over $50 \mathrm{mg}$. per $100 \mathrm{ml}$. on any occasion. The tests were made at least once between two and five years after the onset of symptoms.

Since the children had endured much investigation and treatment in the past, and most were in the pre-school age group when clinical investigation is most difficult, it was considered desirable to limit the study to the minimum required to provide a reasonable estimate of kidney function. Thus tubular function was assessed by the ability to concentrate and acidify the urine and glomerular function by the clearance of creatinine. Since the determination of creatinine clearance by methods which also measure non-creatinine chromogen is not satisfactory (Doxiadis and Goldfinch, 1952; Barnett and 
Vesterdal, 1953), specific endogenous creatinine was measured by Hare's method (1950) using a Unicam SP600 spectrophotometer. Two timed collection periods of between one and two hours were used and the results were expressed in terms of surface area calculated from the Dubois nomogram. Urea clearance was also estimated but in most cases the rate of urine secretion was not adequate for maximum clearance of urea to be determined.

The children were examined at intervals to assess their growth and development and to determine how long the biochemical disorder persisted. Although some of the children had gone abroad or to distant parts of the country it was possible to pursue these investigations more or less completely in all but one of the 14. This child (Case 14) was admitted to hospital at the age of 4 months with characteristic symptoms, a plasma calcium level of $13.5 \mathrm{mg}$. per $100 \mathrm{ml}$., blood urea level of $26 \mathrm{mg}$. per $100 \mathrm{ml}$., and no abnormality of the urine. He was treated with a low-calcium milk preparation and the plasma calcium level had returned to normal by the age of 6 months. At 8 months he weighed $16 \mathrm{lb}$. $5 \mathrm{oz}$. $(7 \cdot 4 \mathrm{~kg}$.$) ; he was not seen again because his family$ were nomadic tinkers and could not be traced.

\section{Results}

General progress. Three to six years after the onset of idiopathic hypercalcaemia, all 13 children were in good health. They were taking a full mixed diet except for one who was a vegetarian from choice. None was taking cod liver oil or additional vitamin D except that in patent cereal foods. Two of the mothers stated that their children were still slightly constipated, otherwise none of them had any complaints. Some of the children had sat up and walked at the usual times but most had been slightly delayed. Nevertheless, all were sitting up without support by 12 months, and all had taken the first unaided step by 21 months. Intelligence was not formally tested but ordinary clinical observation indicated that all the children except one were well up to average mental development for their ages. The one exception (Case 1) showed slight mental retardation at the age of $5 \frac{1}{2}$ years. However, although there had never been radiological abnormalities of her skull, she did have some of the facial characteristics described in the severe type of idiopathic hypercalcaemia (Joseph and Parrott, 1958), namely, a squint, slight epicanthic folds and a prominent upper lip, and thus possibly represented an intermediate form between simple and severe types.

Cardiovascular system. Three children who had had cardiac murmurs during the acute illness had no detectable cardiac abnormality at the most recent examination. Two of the three had originally had $T$ wave abnormalities in the electrocardiogram and these also had disappeared. In none of the 13 children was the blood pressure more than $110 / 80 \mathrm{~mm}$. $\mathrm{Hg}$ at review.

Biochemical investigations. All the children had normal levels of plasma calcium at the last recording (range 9.0-11.1 mg. per $100 \mathrm{ml}$.). Because the level of plasma calcium was determined at irregular intervals in some of the early cases, it was not always possible to be certain exactly when the hypercalcaemia subsided, but the minimum duration was assessed as the time interval between the first diagnosis of hypercalcaemia and the last occasion on which a level of above $12.0 \mathrm{mg}$. per $100 \mathrm{ml}$. was recorded; the Table shows the minimum duration of hypercalcaemia in each case. During the original illness, the plasma alkaline phosphatase level was known to be less than 10 King-Armstrong units in seven of the 13 children; all seven had levels above 10 King-Armstrong units at the latest review. Raised plasma cholesterol levels (over $280 \mathrm{mg}$. per $100 \mathrm{ml}$.) had been recorded in three of the 13 children but in all three the cholesterol level was less than $230 \mathrm{mg}$. per $100 \mathrm{ml}$. at review.

Renal function. In none of the 13 cases did the urine contain protein, sugar or abnormal numbers of cells at the time of review. Tests of renal function were made on the 10 children who had shown evidence of possible renal involvement during the original illness and the results are shown in the Table. In the other three children only concentrating and acidifying abilities were tested. The ages of the children at the time of these tests ranged from 2 years and 5 months to 5 years and 9 months. All the children except one concentrated the urine to a specific gravity of 1.025 or more when fluids were withheld for 12 hours. The one exception (Case 2) concentrated to 1.023 ; no opportunity arose to repeat the test on this child. All the children were able to acidify the urine to $p \mathrm{H} 5 \cdot 2$ or less, measured with universal indicator and narrow range indicator papers (B.D.H.). In five of the children it was necessary to give ammonium chloride by mouth in a dose of $0.1 \mathrm{~g}$. per $\mathrm{kg}$. of body weight in order to demonstrate this acidifying ability.

The creatinine clearance was more than $75 \mathrm{ml}$. per min. per $1.73 \mathrm{~m}^{2}$ of surface area in seven of the 10 children tested, while in three it was between 60 and 75 . In two of these three (Cases 8 and 12), however, the creatinine determinations were done in a different laboratory, and total Jaffé chromogens 
were measured instead of specific endogenous creatinine. The results would thus be expected to be falsely depressed (Roscoe, 1958) and unfortunately the tests could not be repeated in these two children using Hare's method (1950). However, the maximum and standard clearances in Case 12, and the standard urea clearance in Case 8 , were all more than $100 \%$ of average normal, and it is likely that the true creatinine clearance was considerably higher. One child (Case 4) with a clearance of specific endogenous creatinine of $65.5 \mathrm{ml}$. per min. per $1.73 \mathrm{~m} .^{2}$ was aged $3 \frac{1}{2}$ years at the time of the test. There are no satisfactory standards of normal for children of this age, and the clearance value, though low, cannot be regarded as necessarily abnormal, especially as a simultaneous urea clearance test indicated a standard clearance of $117 \%$ of average normal.

The standard urea clearance was over $100 \%$ of average normal in nine of the 10 children; in three (Cases 2, 11 and 12) the maximum clearance of urea was also determined, each value being above $100 \%$ of average normal. The only child with a low standard urea clearance ( $58 \%$ of average normal) was the one suspected of having a form of idiopathic hypercalcaemia intermediate between the simple and severe types, but since the other tests were satisfactory (see Table), this rather low value is of dubious significance.

Growth progress. The heights and weights of the 13 children were measured at intervals throughout the follow-up period, and these, together with measurements made during the illness and any recorded by the mother before admission to hospital, have been plotted on height and weight charts (Figs. 1 and 2). The standards used for these charts are derived from the Oxford Child Health Survey (Acheson, Kemp and Parfit, 1955) and standard deviations (S.D.) from the mean values are shown because only these were published. The -2 and -1 S.D. lines correspond to about the $2 \cdot 25$ th and 16th percentiles respectively, and the +1 and +2 S.D. lines to about the 84 th and $97 \cdot 75$ th percentiles, the error due to the asymmetry of the distribution curve for weight being quite small (Polani, 1959). When weighed, the children were naked or wearing underpants, and height was measured in the standing position (in children over 18 months of age).

Nearly every weight chart shows clearly the deviation of the weight curve during the first two years of life caused by the hypercalcaemic episode and the subsequent return to the original channel. The data on heights are fewer in number and no clear effect on height is demonstrated. In no case is either the height curve or the weight curve still pursuing a course outside the -2 S.D. line. In two cases the height curves are between the -2 and -1 S.D. lines, and in one other case the weight curve is between the -2 and -1 S.D. lines.

\section{Discussion}

The tests of renal function did not reveal any significant abnormality in this group of children two to five years after the onset of idiopathic hypercalcaemia. Thus, the ability to concentrate and acidify the urine satisfactorily showed that tubular function was unimpaired. The inulin clearance test, which is generally regarded as a valid measure of glomerular filtration rate, is not easily applicable to young children, and so the clearance of specific endogenous creatinine was used when possible as an indication of glomerular function. This would

TABLE

SUMMARY OF BIOCHEMICAL FINDINGS AND RENAL FUNCTION TESTS IN 14 CASES OF IDIOPATHIC HYPERCALCAEMIA

\begin{tabular}{|c|c|c|c|c|c|c|c|c|c|}
\hline \multirow[b]{2}{*}{$\begin{array}{l}\text { Case } \\
\text { No. }\end{array}$} & \multirow[b]{2}{*}{ Sex } & \multirow[b]{2}{*}{$\begin{array}{c}\text { Maximum } \\
\text { Level of } \\
\text { Calcium } \\
\text { in Plasma } \\
(\mathrm{mg} . / 100 \mathrm{ml} .)\end{array}$} & \multirow[b]{2}{*}{$\begin{array}{c}\text { Minimum } \\
\text { Duration } \\
\text { of Hyper- } \\
\text { calcaemia } \\
(>12 \cdot 0 \mathrm{mg} . / 100 \mathrm{ml} .)\end{array}$} & \multirow[b]{2}{*}{$\begin{array}{l}\text { Maximum } \\
\text { Level of } \\
\text { Urea in } \\
\text { Blood } \\
\text { (mg. } / 100 \mathrm{ml} .)\end{array}$} & \multirow[b]{2}{*}{ 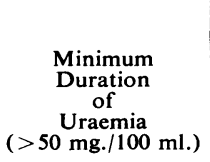 } & \multicolumn{4}{|c|}{ Tests of Renal Function } \\
\hline & & & & & & $\begin{array}{c}\text { Time in } \\
\text { Years } \\
\text { Between } \\
\text { Onset } \\
\text { and Tests }\end{array}$ & $\begin{array}{c}\text { Creatinine } \\
\text { Clearance } \\
\text { (ml./min./ } \\
\left.1.73 \mathrm{m.} .^{2}\right)\end{array}$ & $\begin{array}{c}\text { Minimum } \\
p \mathrm{H} \text { of } \\
\text { Urine }\end{array}$ & $\begin{array}{c}\text { Maximum } \\
\text { S.G. of } \\
\text { Urine }\end{array}$ \\
\hline $\begin{array}{r}1 \\
2 \\
3 \\
4 \\
5 \\
6 \\
7 \\
8 \\
9 \\
10 \\
11 \\
12 \\
13 \\
14\end{array}$ & \begin{tabular}{l|}
$\mathbf{F}$ \\
$\mathbf{F}$ \\
$\mathbf{F}$ \\
$\mathbf{F}$ \\
$\mathbf{F}$ \\
$\mathbf{F}$ \\
$\mathbf{F}$ \\
$\mathbf{F}$ \\
$\mathbf{F}$ \\
$\mathbf{F}$ \\
$\mathbf{M}$ \\
$\mathbf{M}$ \\
$\mathbf{M}$ \\
$\mathbf{M}$
\end{tabular} & $\begin{array}{l}16 \cdot 8 \\
14 \cdot 0 \\
13 \cdot 9 \\
13 \cdot 0 \\
15 \cdot 1 \\
16 \cdot 1 \\
19 \cdot 0 \\
16 \cdot 0 \\
13 \cdot 4 \\
13 \cdot 3 \\
15 \cdot 6 \\
13 \cdot 3 \\
14 \cdot 0 \\
13 \cdot 5\end{array}$ & $\begin{array}{c}5 \text { months } \\
28 \text { months } \\
3 \text { months } \\
2 \text { weeks } \\
1 \text { week } \\
4 \text { weeks } \\
2 \text { weeks } \\
3 \text { weeks } \\
2 \text { weeks } \\
1 \text { week } \\
3 \text { months } \\
8 \text { months } \\
4 \text { weeks } \\
2 \text { weeks }\end{array}$ & $\begin{array}{r}135 \\
58 \\
76 \\
48 \\
46 \\
60 \\
63 \\
60 \\
29 \\
37 \\
40 \\
72 \\
50 \\
50\end{array}$ & $\begin{array}{c}7 \text { months } \\
2 \text { weeks } \\
4 \text { weeks } \\
\text { nil } \\
\text { nil } \\
2 \text { weeks } \\
2 \text { weeks } \\
1 \text { week } \\
\text { nil } \\
\text { nil } \\
\text { nil } \\
8 \text { months } \\
\text { nil } \\
\text { nil }\end{array}$ & $\begin{array}{l}5 \\
4 \\
3 \frac{1}{2} \\
3 \\
2 \frac{3}{4} \\
2 \frac{1}{2} \\
2 \frac{1}{2} \\
2 \\
3 \frac{1}{2} \\
3 \frac{1}{4} \\
5 \\
41 \\
5 \\
\end{array}$ & $\begin{array}{r}103 \cdot 9 \\
115 \cdot 5 \\
78 \cdot 9 \\
65 \cdot 5 \\
99 \cdot 9 \\
98 \cdot 2 \\
77 \cdot 3 \\
64 \cdot 6 \\
- \\
103 \cdot 9 \\
62 \cdot 3 \\
-\end{array}$ & $\begin{array}{r}<5.0 \\
<5.0 \\
<5.0 \\
5.2 \\
<5.0 \\
5.0 \\
<5.0 \\
5.0 \\
<5.0 \\
5.2 \\
<5.0 \\
5.0 \\
<5.0 \\
\end{array}$ & $\begin{array}{l}1.028 \\
1.023 \\
1.030 \\
1.028 \\
1.030 \\
1.026 \\
1.025 \\
1.027 \\
1.029 \\
1.025 \\
1.028 \\
1.025 \\
1.025 \\
-\end{array}$ \\
\hline
\end{tabular}




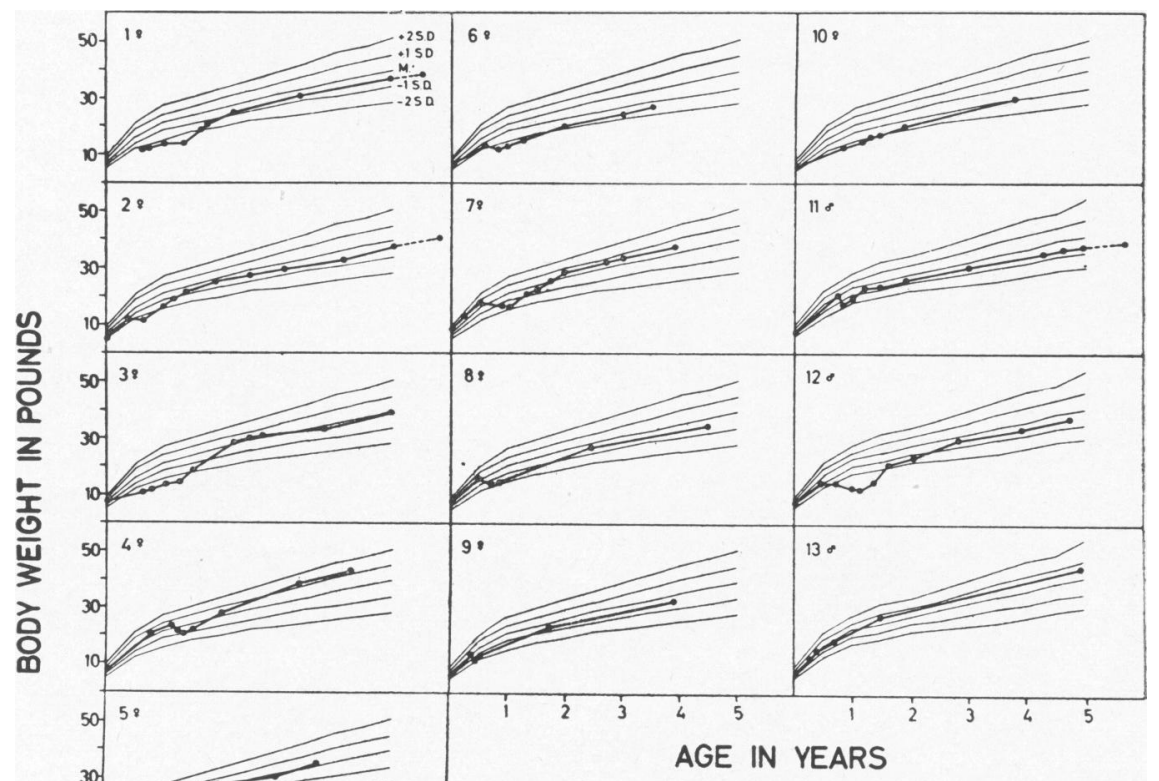

FIG. 1.-Weight charts of 13 children who had idiopathic hypercalcaemia in infancy. Cases 1 to 10 are girls and Cases

11 to 13 are boys. (S.D. $=$ standard deviation: $\mathbf{M}=$ mean).

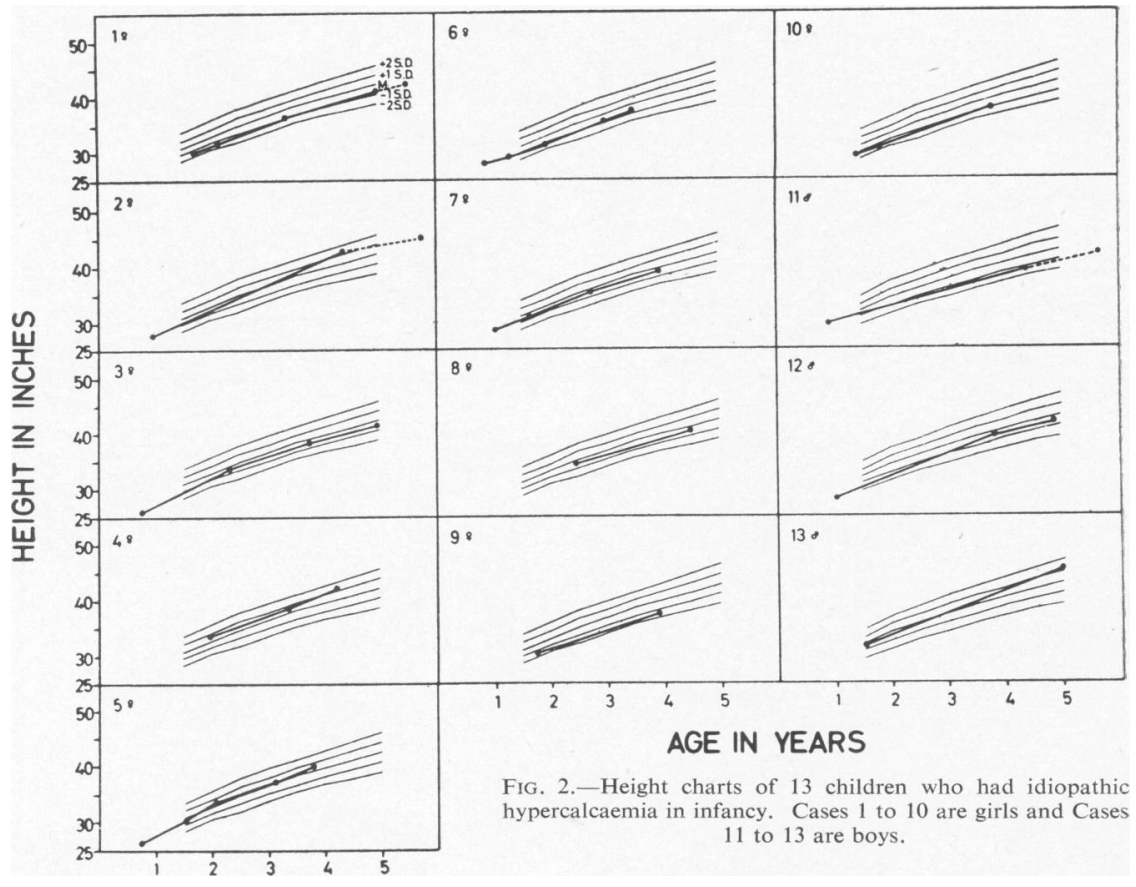


be valid in children with disease affecting the renal tubules (Mattar, Barnett, McNamara and Lauson, 1952), but the evidence indicated that all these children had normal tubular function, and the creatinine clearance was therefore accepted as an approximate measure of glomerular filtration. The values obtained are somewhat lower than those recorded by Ikkos and Ström (1955) for older children, but all fall within a fairly small range and are considered to indicate satisfactory glomerular function.

It is well established that persistent hypercalcaemia can cause renal damage, calculus formation and calcification (Thomas, Connor and Morgan, 1959) and it is therefore remarkable that one child (Case 2), who was known to have had hypercalcaemia for at least 28 months, should have apparently completely normal renal function at the age of $4 \frac{1}{2}$ years. In the earliest patients, who were treated by withdrawal of vitamin D alone, the hypercalcaemia was allowed to persist much longer than in the later ones, in whom active measures were taken to reduce the level of plasma calcium. Low calcium diets alone were not always successful in reducing the level promptly but a rapid fall usually followed the administration of cortisone, and this action was sometimes used to maintain the plasma calcium at a lower level until the reduction in calcium intake could become effective.

The way in which cortisone acts is not understood, although its beneficial effect in idiopathic hypercalcaemia of infants may in part be due to reduced absorption of calcium from the intestine (Anderson, Dent, Harper and Philpot, 1954; Morgan et al., 1956). In an attempt to throw further light on the mode of action of cortisone, the level of plasma calcium was measured in four untreated hypercalcaemic infants before, and at short intervals after, a single oral dose of cortisone (Fig. 3). The rate of fall in the plasma calcium level indicates that some mechanism more rapid than the intestinal action must be operating initially. This cannot be a renal tubular effect, since there was no increase in calcium in the urine during these tests. It has been postulated by Cruickshank and Kodicek (1958) that cortisone acts by influencing the metabolism of skeletal tissues and there is indirect evidence that cortisone can inhibit the resorption of bone (Thomas and Morgan, 1958; Morgan, 1959).

The charts for height and weight indicate satisfactory growth progress during the years immediately following clinical recovery from the simple type of idiopathic hypercalcaemia. There is no apparent association between the rate of return to the expected growth channel and the duration or degree of either

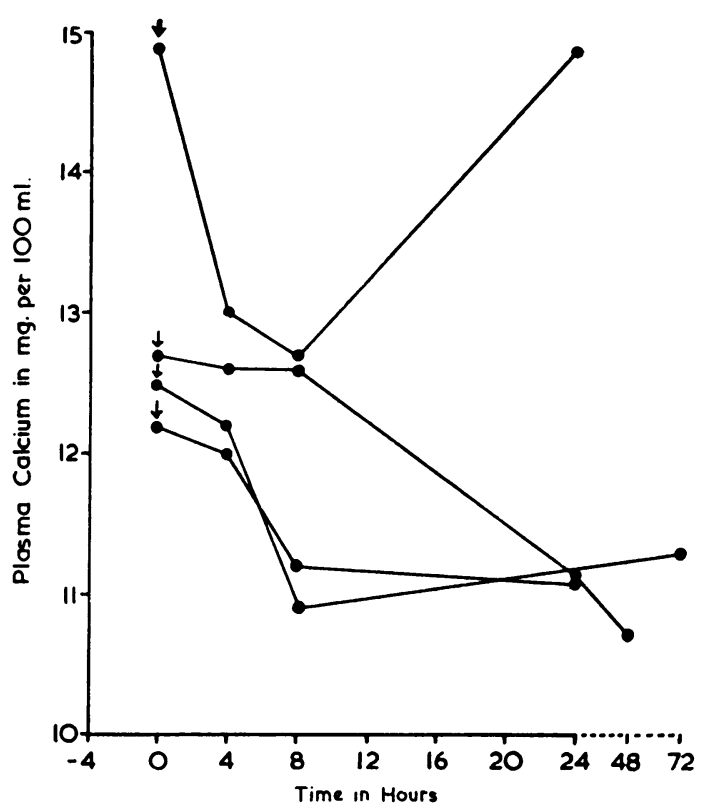

FIG. 3.-The effect of cortisone on the plasma calcium level in four cases of idiopathic hypercalcaemia. (The arrow indicates $25 \mathrm{mg}$. cortisone acetate given orally.)

the hypercalcaemia or the elevation of blood urea. Thus the child who was known to have had hypercalcaemia for at least 28 months (Case 2) was above average in height. Her weight curve did pursue a course below the mean level, but this was probably not attributable to the prolonged metabolic disturbance, since height as well as weight has usually been affected by persistent elevation of plasma calcium in cases of the severe type of idiopathic hypercalcaemia, as it was also in the patient described by Smith et al. (1959), who seems to have had the simple type of idiopathic hypercalcaemia.

This investigation provides evidence in support of the opinions of earlier workers that recovery from the simple type of idiopathic hypercalcaemia is usually complete. Nevertheless, the possibility of unexpected death in the acute stage (Rhaney and Mitchell, 1956), the recognition of cases intermediate between simple and severe forms of idiopathic hypercalcaemia, and the prolonged course occasionally followed by apparently simple cases (Smith et al., 1959), should make one hesitate to give an unreservedly good prognosis for the individual child.

\section{Summary}

Thirteen cases of the simple type of idiopathic hypercalcaemia of infants have been followed up 
for three to six years after the onset of the illness.

All the children are in good health and all except one are mentally normal, the one exception having certain features suggesting a syndrome intermediate between the simple and severe types.

In all cases the abnormal biochemical findings originally present have disappeared. Simple tests of renal function performed two to five years after the onset did not indicate any residual impairment of renal function.

Although the hypercalcaemic episode caused a marked deviation of the weight curve in nearly every child, the height and weight charts indicate that subsequent progress has been satisfactory.

I wish to thank Professor J. L. Henderson and Dr. James Thomson for permission to include their cases in this study and for their kindly criticism. I am very grateful to Dr. F. L. Mitchell and Dr. H. G. Morgan for the biochemical investigations and for helpful advice. I also thank Miss M. W. Mackenzie for the illustrations.

\section{REFERENCES}

Acheson, R. M., Kemp, F. H. and Parfit, J. (1955). Height, weight and skeletal maturity in the first five years of life. Lancet, 1,691 .

Anderson, J., Dent, C. E., Harper, C. and Philpot, G. R. (1954). Effect of cortisone on calcium metabolism in sarcoidosis with hypercalcaemia. Ibid., 2, 720.

Barnett, H. L. and Vesterdal, J. (1953). The physiologic and clinical significance of immaturity of kidney function in young infants. J. Pediat., 42, 99.

Carter, R. E. Bonham, Dent, C. E., Fowler, D. I. and Harper, C. M. (1955). Calcium metabolism in idiopathic hypercalcaemia of
infancy with failure to thrive. Arch. Dis. Childh., 30, 399.
Creery, R. D. G. and Neill, D. W. (1954). Idiopathic hypercalcaemia in infants with failure to thrive. Lancet, 2,110

Cruickshank, E. M. and Kodicek, E. (1958). The antagonism between cortisone and vitamin D: experiments on hypervitaminosis $D$ in rats. $J$. Endocr., 17, 35 .

Doxiadis, S. A. and Goldfinch, M. K. (1952). Comparison of inulin and "endogenous creatinine" clearances in young children. J. Physiol. (Lond.), 118, 454.

Fellers, F. X. and Schwartz, R. (1958). Etiology of the severe form of idiopathic hypercalcemia of infancy. New Eng. J. Med., 259, 1050.

Forfar, J. O., Balf, C. L., Maxwell, G. M. and Tompsett, S. L. (1956). Idiopathic hypercalcaemia of infancy. Lancet, 1,981 .

Hare, R. S. (1950). Endogenous creatinine in serum and urine. Proc. Soc. exp. Biol. (N.Y.) 74, 148 .

Ikkos, D. and Ström, L. (1955) A comparison of the endogenous creatinine and inulin clearances in children. Acta paediat. (Uppsala), 44, 426.

Joseph, M. C. and Parrott, D. (1958). Severe infantile hypercalcaemia with special reference to the facies. Arch. Dis. Childh., 33, 385.

Lightwood, R. and Stapleton, T. (1953). Idiopathic hypercalcaemia in infants. Lancet, 2, 255 .

Lowe, K. G., Henderson, J. L., Park, W. W. and McGreal, D. A. (1954). The idiopathic hypercalcaemic syndromes of infancy. Ibid., $2,101$.

Mattar, G., Barnett, H. L., McNamara, H. and Lauson, H. D. (1952). Measurement of glomerular filtration rate in children with kidney disease. J. clin. Invest., 31, 938 .

Mitchell, R. G. (1958). Idiopathic hypercalcaemia of infants. Proc. Nutr. Soc., 17, 71 .

Morgan, H. G. (1959). Personal communication.

Mitchell, R. G., Stowers, J. M. and Thomson, J. (1956) . Metabolic studies on two infants with idiopathic hypercalcaemia. Lancet, 1, 925.

Polani, P. E. (1959). Personal communication.

Rhaney, K. and Mitchell. R. G. (1956). Idiopathic hypercalcaemia of infants. Lancet, 1, 1028.

Roscoe, M. H. (1958). Plasma chromogen and the endogenous creatinine clearance. J. clin. Path., 11, 173.

Russell, A. and Young, W. F. (1954). Severe idiopathic infantile hypercalcaemia: long-term response of 2 cases to low calcium hypercalcaemia: long-term response

Schlesinger, B. E., Butler, N. R. and Black, J. A. (1956). Severe type of infantile hypercalcaemia. Brit. med. J., 1, 127

Smith, D. W., Blizzard, R. M. and Harrison, H. E. (1959). Idiopathic hypercalcaemia. Pediatrics, 24, 258.

Thomas, W. C., Connor, T. B. and Morgan, H. G. (1959). Diagnostic considerations in hypercalcemia. New Eng. J. Med., 260, 591 and Morgan, H. G. (1958). The effect of cortisone in experimental hypervitaminosis D. Endocrinology, 63. 57. 